\title{
Impaired Interleukin-2 Receptor Expression on Lymphocytes from Patients with Chronic Active Hepatitis Type B
}

\author{
Deuk Soo Ahn, M.D., Hyun Cheol Jang, M.D., Joong Ki Ahn, M.D. \\ Chang Yeol Yim, M.D. and Dae Ghon Kim, M.D.
}

Department of Internal Medicine, Chonbuk National University, Chonbuk, Chonju, Korea

\begin{abstract}
To evaluate cell mediated immunopathogenic mechanisms in chronic hepatitis $B$ virus (HBV) infection, we investigated the changes of $T_{4} / T_{8}$ ratios from the peripheral blood, the percentages of $(L-2$ receptor expression after stimulation of mitogens (Con A, PHA) and a specific antigen (Hepatitis type $B$ surface antigen, HBs), and the proliferative response mediated by $(L-2$ receptors after rIL-2 stimulation on mixed mononuclear cell. These experiments were performed comparatively in 5 groups which consisted of serologically negative normal subjects, chronic HBV carriers, patients with chronic active hepatitis (CAH) type $B$, patients with acute hepatitis $(A H)$ type $B$, and the antibody positive healthy subjects.

There were significant decreases of $T_{4} / T_{8}$ ratios in chronic $H B V$ carriers, in patients with $C A H$ type $B$, and in patients with $A H$ type $B$, compared with negative normal controls. There were no significant differences between patients with $C A H$ type $B$ and the HBs negative normal controls in the percentage of $\mathrm{L}-2$ receptor positive cells after in-vitro HBs-stimulation and the proliferative response assessed by the incorporation of ${ }^{3} \mathrm{H}$-thymidine, whereas in patients with $\mathrm{AH}$ type $B$ there were significant increases in both. Thus, in addition to a relatively decreased $T_{4} / T_{8}$ ratio, the impairment of $/ L-2$ receptor expression on the lymphocytes after HBs-stimulation caused a defective response of cellular proliferation, and this might be one of the leading immunopathogenic roles in chronic HBV infection.
\end{abstract}

Key Words: Chronic active hepatitis (CAH) type B, $1 L-2$ receptor expression, Immunopathogenic role

\section{INTRODUCTION}

It has been demonstrated that host factors are involved in the pathogenesis of hepatocellular injury in hepatitis $B$ virus (HBV) infection, since HBV does not appear to be directly cytopathic for hepatocytes in patients with the chronic carrier state, and the diversities in infected patients are attributed to variation in the capacity of the host immune response to eliminate or suppress the infective agent. The interaction of interleukin-2 (IL-2) with its receptor on the activated cytolytic T lymphocytes (CTL) would

Address reprint requests: Deuk Soo Ahn, M.D., Department of internal Medicine, Chonbuk National University School of Medicine and Hospital, Chonju 560-182, Korea

This work was supported by Chonbuk National University Research Funds. provide the primary stimulus for CTL proliferation. ${ }^{17}$ These IL-2 receptors are not present on the surface of $T$ lymphocyte precursors. Thus it has been postulated that the role of antigen or mitogen is to induce differentiation of the inactive precursor to the mature form. ${ }^{18)}$ In addition, it was reported that the proliferative response of human virus-specific cytotoxic $T$ lymphocytes is dependent on the level of IL-2 receptor expression rather than IL-2, and the IL-2 receptor expression was indeed transient and dependent on antigenic stimulation for reexpression. ${ }^{19)}$ Despite continuous HBsAg stimulation in patients with chronic active hepatitis and in patients who are chronic carriers, the cell mediated immunity (CMI) which accounts partly for proliferation and cytotoxicity of CTL is ineffective for elimination of the virus and virus infected hepatocytes. Therefore, it would be expected that impairment of IL-2 recep- 


\section{IMPARIED INTERLEUKIN-2 RECEPTOR EXPRESSION ON LYMPHOCYTES FROM PATIENTS WITH CHRONIC ACTIVE HEPATITIS TYPE B}

tor expression is relevant to the defective $\mathrm{CMI}$ patient with chronic HBV infection. So in this paper, we investigated the cause of defective $\mathrm{CMI}$, which arises from impairment of IL-2 receptor expression on lymphocytes, in patients with chronic HBV infection. We intended to determine firstly whether an underlying abnormal proportion of $T$ cell subsets was related to defective $\mathrm{CMl}$; secondly, whether the impairment of IL-2 receptor expression was related to defective $\mathrm{CMI}$, and thirdly whether subsequent abnormal proliferation of the lymphocytes was associated with the impairment of IL-2 receptor expression.

\section{MATERIALS AND METHODS}

\section{Subjects}

The study population consisted of patients divided into five categories. There were recovered patients with hepatitis $B$ antibody (anti-HBs) patients with acute hepatitis $(A H)$ type $B$, patients with chronic active hepatitis (CAH) type $B$, healthy chronic HBV carriers, and matched with the patients for age and sex were negative control subjects. The liver diseases were diagnosed by biochemical evidence, duration, and physical findings and were confirmed by biopsies. The tests for serologic markers of HBV were conducted using the enzyme-linked immunosorbent assay (Organon, Netherlands) (Table 1).

\section{Preparation of the Peripheral Blood Mononuclear Cells}

Peripheral blood mononuclear (PBM) cells were separated from heparinized venous blood with Ficoll-
Hypaque gradient (specific gravity 1.078 ) at $400 \mathrm{~g}$ for $30 \mathrm{~min}$. The cells collected from the interface were washed 3 times with Hank' balanced salt solution (HBSS) (GIBCO, Grand Island, NY) containing 5\% heat-inactivated fetal calf serum (FCS) (GIBCO), and suspended in culture medium. The mononuclear cell concentration was adjusted to $1 \times 10^{6}$ per mililiter in culture medium.

\section{Cell-Culture Conditions}

RPMI 1640 (GIBCO) supplemented with $100 \mathrm{IU}$ penicillin, $100 \mu \mathrm{g} / \mathrm{ml}$ streptomycin and $10 \%$ heat inactivated fetal calf serum (FCS) was used as the culture medium. PBM cells were suspended in culture medium and plated on 96-well round bottomed culture plates $(\mathrm{GIBCO})$ at $2 \times 10^{5}$ cells per $0.2 \mathrm{~m}$. per well for 72 hours in a $5 \% \mathrm{CO}_{2} / 95 \%$ humiditied air environment. As inducer of $\mathrm{IL}-2$ receptor expression, mitogens such as phytohemagglutinin (PHA, Sigma Chemical Co., St. Louis, MO) $(2 \mu \mathrm{g} / \mathrm{ml})$ or concanavalin A (Con A, Sigma) $(2 \mu \mathrm{g} / \mathrm{ml})$ and hepatitis $\mathrm{Bs}$ antigen (HBs, Green Cross Co., Suwon) $2 \mu \mathrm{g}$ protein $/ \mathrm{ml}$, and ovalbumin (OVA, Sigma) $(2 \mu \mathrm{g} / \mathrm{ml})$ were added to the control wells before cultivation. All cultures were set up in triplicate.

\section{Directed Immunofluorescence}

The $C D_{4} / C_{8}$ ratio was examined and calculated using $T$ cell monoclonal antibody from Becton Dickinson which was a fluorescein isothiocyanate (FITC) conjugate of Anti-Leu-3a for Thelper cells and a conjuate of Anti-Leu-2a for suppressor/cytotoxic cells respectively. Both antibodies are detected under fluorescein conditions using a standard fluorescence microscope by a direct im-

Table 1. The Characteristics of Subjects Investigated

\begin{tabular}{|c|c|c|c|c|}
\hline Group & Number $(F / M)$ & $\begin{array}{c}\text { Mean } \\
\text { Age (yrs) }\end{array}$ & LFT & $\begin{array}{l}\text { Positive Serologic } \\
\text { marker for } \mathrm{HBV}\end{array}$ \\
\hline Negative normal control & $5(2 / 3)$ & 27 & Normal & all negative \\
\hline HBV carrier & $3(1 / 2)$ & 39 & Normal & HBs, IgG anti-HBc, $\mathrm{HBe}$ \\
\hline $\mathrm{CAH}$ & $6(2 / 4)$ & 27 & Abnormal & $\mathrm{HBs}, \mathrm{lgG}$ anti-HBc, $\mathrm{HBe}$ \\
\hline $\mathrm{AH}$ & $3(1 / 2)$ & 43 & Abnormal & $\mathrm{HBs}, \mathrm{IgG}$ anti-HBc, HBe \\
\hline Antibody positive control & $6(1 / 5)$ & 33 & Normal & anti-HBs lgG anti-HBc, anti-HBe \\
\hline $\mathrm{CAH}$ : chronic active hepatitis & \multicolumn{3}{|c|}{ HBs: hepatitis B $s$ antigen } & \\
\hline AH : Acute hepatitis & \multicolumn{3}{|c|}{ HBe : hepatitis $\mathrm{B}$ e antigen } & \\
\hline HBV : hepatitis B virus & \multicolumn{4}{|c|}{ IgG anti-HBC: immunoglobulin $\mathrm{G}$ hepatitis $\mathrm{C}$ antibody } \\
\hline LFT : liver function tests & \multicolumn{4}{|c|}{ IgM: anti-HBc: immunoglobin $M$ hepatitis $C$ antibody } \\
\hline
\end{tabular}


munofluorescence method. The IL-2 receptor positive cells were determined by a direct immunofluorescence method with anti-interleukin-2 receptor (CD25) conjugated with FITC from Becton Dickinson. Fifty $\mu$ l of the cell suspension at a concentration of $2 \times 10^{7}$ cells $/ \mathrm{ml}$ was added into the microtiter well, which contained $50 \mu$ l of tenfold diluted antibody, and incubated for 30 minutes on ice. After centrifugation at $100 \mathrm{~g}$ for $3 \mathrm{~min}$ at $4^{\prime} \mathrm{C}$, the supernatant was carefully aspirated and discarded, subsequent washings were done twice with cold medium and the cell suspension was recentrifuged. Thereafter, over the drop of resuspended cells on a microscope slide, a cover slip was placed and the slide was examined under the fluorescence microscope with epi-illumination (American Optical, Buffalo, NY). A total of 200 cells were counted and we discriminated the apple green colors representing $T$ helper cells or suppressor/cytotoxic cells with an exciting and barrier filter.

\section{Celiular Proliferation Assay}

The proliferation response was estimated by the rate of uptake of tritiated thymidine $\left({ }^{3} \mathrm{H}-\mathrm{Tdr}, \mathrm{mCi} / \mathrm{mM}\right.$, NEN, Boston, MA) of mixed mononulcear cells in RPMI 1640 supplement added to each well of the microtiter plates at $2 \times 10^{5}$ and cultivated for $72 \mathrm{hrs}$ under pure recombinant IL-2 (rlL-2, Sigma) $(20 \mu / \mathrm{ml})$ stimulation. A pulse of $0.5 \mathrm{uCi}$ of tritiated thymidine was given during the last $12 \mathrm{hr}$ of cell culture. The cells were harvest onto glass fiber filter paper using an automatic cell harvester (Titertek, Flow Lab., UK.). The amount of tritiated thymidine incorporated into cellular DNA was determined by liquid scintillation counting. The results were expressed as the mean counts per minute (cpm) for triplicate determinations. Statistical analysis was done by using the student's t-test.

\section{RESULTS}

\section{Comparison of $T_{4} / T_{3}$ Ratio in Five Groups}

These experiments were performed in mixed mononuclear cells. In cell mediated immune reaction, $\mathrm{T}$ lymphocytes and macrophages/monocytes play major roles and have an interaction. The variation of the fraction of $T$ cell subsets has been reported to be related to the immunopathogenesis of the disease. So before cultivation, the $T_{4} / T_{8}$ ratio was calculated and analyzed in each group.

In each group, the T cell subsets were determin- ed by staining with FITC conjugated with monoclonal antibody, Anti-Leu-3a $\left(\mathrm{CD}_{4}\right)$ and Anti-Leu-2a $\left(\mathrm{CD}_{8}\right)$, and the $T_{4} / T_{8}$ ratio was calculated and analyzed statistically. The relative proportion of $\mathrm{CD}_{4}$ was higher in the antibody positive control and in the negative normal control. As shown in Table 2, the $T_{4} / T_{8}$ ratio was 1.68 in serologically negative normal controls but was 1.18 in chronic HBV carriers, 1.18 in patients with $\mathrm{CAH}$ type $\mathrm{B}, 0.90$ in patients with $A H$ type $B$ and 1.42 in serologically anti-HBs positive healthy controls. As a result, there were significant decreases of the $T_{4} / T_{8}$ ratio in patients with $\mathrm{CAH}$ type $\mathrm{B}$, in chronic carriers, and in patients with $\mathrm{AH}$, compared with the negative normal controls (Table 2).

Table 2. The $T_{4} / T_{8}$ Ratios in the Five Groups

\begin{tabular}{ll}
\hline \hline Group $(n)$ & $T_{4} / T_{8}$ Ratio \\
\hline Negative normal control (5) & $1.68 \pm 0.15$ \\
HBV carrier (3) & $1.17 \pm 0.13^{\star}$ \\
CAH (6) & $1.18 \pm 0.08^{*}$ \\
AH (3) & $0.90 \pm 0.10^{\star *}$ \\
Antibody positive control (6) & $1.42 \pm 0.07$ \\
\hline mean \pm SE & \\
*: $p<0.05$ & \\
$* \star *: p<0.01$ &
\end{tabular}

\section{Fluorescence Analysis of the IL-2 Receptor Expression}

After stimulation by mitogens and antigens, IL-2 receptor expression was examined by immunofluorescence microscopy with direct immunofluorescence stain, and the percentage of receptor positive cells was calculated and compared in each group after stimulation. We used ovalbumin (OVA) as the nonspecific antigen, $\mathrm{HBs}$ as the specific antigen, and PHA and Con $A$ as polyclonal $T$ cell mitogens. The nonspecific antigen induced little IL-2 receptor expression in negative nomral controls and in the other groups, so that there was no difference between the normal controls and other groups. As Table 3 shows, after stimulation of mitogens (Con A, PHA) there was no significant difference between each group and the control group. The fraction of IL-2 receptor positive cells was calculated after specific antigenic (HBs) stimulation. The percentage of receptor positive cells was $27.2 \%$ in the antibody positive control group, and $21.2 \%$ in patients with $\mathrm{AH}$ type $\mathrm{B}$. There were significant increases. In con- 
Table 3. The Percentages of IL-2 Receptor Positive Cells after Mitogens or HBs Stimulation in Four Groups

\begin{tabular}{|c|c|c|c|c|}
\hline \multirow[b]{2}{*}{ Group } & \multicolumn{4}{|c|}{ Stimulant } \\
\hline & Con $A(2 \mu g / m i)$ & $\mathrm{PHA}(2 \mu \mathrm{g} / \mathrm{ml})$ & $\mathrm{HBs}(2 \mu \mathrm{g} / \mathrm{mI})$ & $\mathrm{OVA}(2 \mu \mathrm{g} / \mathrm{ml})$ \\
\hline Negative normal control & $73.0 \pm 5.7$ & $78.0 \pm 8.2$ & $10.6 \pm 2.3$ & $9.2 \pm 2.5$ \\
\hline $\mathrm{CAH}$ & $68.2 \pm 4.2$ & $61.0 \pm 7.2$ & $17.0 \pm 2.6$ & $8.4 \pm 1.7$ \\
\hline $\mathrm{AH}$ & $72.1 \pm 10.6$ & $74.2 \pm 11.3$ & $21.2 \pm 3.8^{*}$ & $6.5 \pm 1.5$ \\
\hline Antibody positive control & $76.2 \pm 9.2$ & $76.3 \pm 7.0$ & $27.2 \pm 2.9^{* *}$ & $7.7 \pm 1.6$ \\
\hline
\end{tabular}

Con A: concanavalin A, PHA: phytohemagglutinin, HBs: hepatitis $B$ surface antigen, OVA: ovalbumin mean $\pm S E$

*: $p<0.05$

**: $p<0.01$

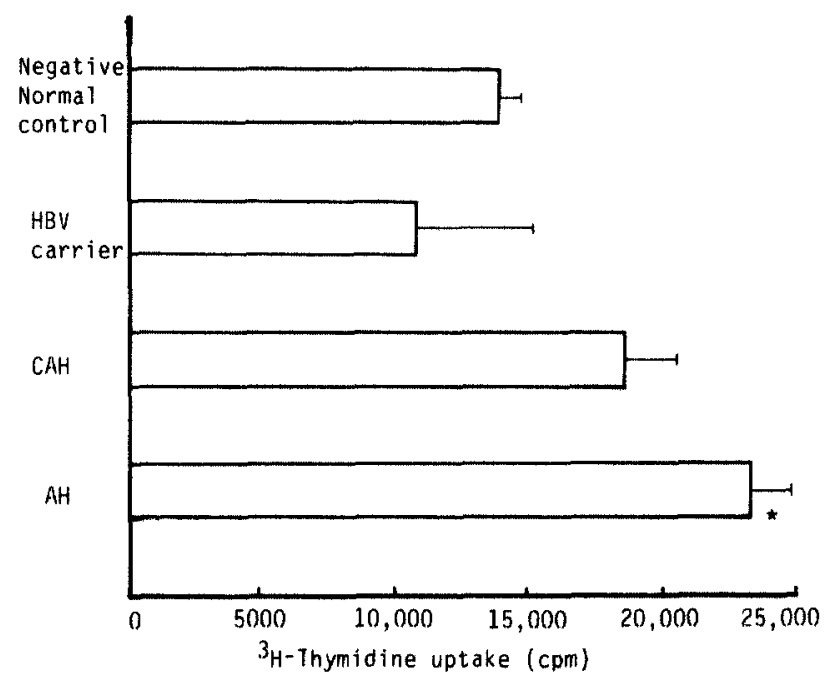

Fig. 1. The proliferative response of mononuclear cells at $2 \times 10^{s}$ cells stimulated by $\mathrm{r} / \mathrm{L}-2(20 \mathrm{u} / \mathrm{ml})$ atter a pulse of $0.5 \mu \mathrm{Ci}$ of ${ }^{3} \mathrm{H}$-thymidine during the last $12 \mathrm{hrs}$ of cell cultivation for $72 \mathrm{hrs}$ in each group. Results are the means of triplicate samples $\pm S E(n=3)$.

$* 0<0.05$

trast, the percentage of receptor positive cells was $17 \%$ in patients with $\mathrm{CAH}$ type $\mathrm{B}$, and there was no significant difference as compared to that of the negative normal control group. Under nonspecific antigenic stimulation, the percentage of receptor positive cells was less than $9 \%$ in each group (Table 3).

\section{Cellular Proliferation Assay}

As Fig. 1 showed, the proliferative response after stimulation of rlL-2 was assayed by thymidine uptake on the 3rd day of cultivation. There was similiar thymidine uptake in the chronic HBV carrier group $(10,858 \pm 4,424 \mathrm{cpm})$ and in the chronic active hepatitis group $(18,678 \pm 1,902 \mathrm{cpm})$ as compared with that of the negative control group $(13,874 \pm 934$ $\mathrm{cpm}$ ). But the level of thymidine uptake in the group with $\mathrm{AH}$ type $\mathrm{B}(23,436 \pm 1,551 \mathrm{cpm})$ was significantIy higher than that of the negative control group.

\section{DISCUSSION}

In the previous study, an increased proportion of suppressor/cytotoxic lymphocytes were identified in the peripheral blood of HBs positive patients. Thomas et al." reported a reduction in the $T_{4} / T_{8}$ ratios in the peripheral blood of patients with HBs positive chronic liver diseases who were predominantly $\mathrm{HBe}$ positive, while the $T_{4} / T_{B}$ ratios were normal in those with minimal liver darnage who were predominantly anti-HBe positive. The reduc- 
ed ratios were attributed to either liver damage or to viral replication, and while the latter seemed more likely, no definite conclusion could be reached. However, in a more recent study, it was concluded that altered proportions of $\mathrm{T}$ cell subsets in chronic $\mathrm{HBV}$ infection were related to the altered immune status seen in homosexuals. ${ }^{\text {s }}$ So we reinvestigated the $T_{4} / T_{8}$ ratios in patients with $C A H$ type $B$ as compared with serologically negative subjects. Also, we observed that there were decreased $T_{4} / T_{8}$ ratios in patients with $\mathrm{CAH}$ type $\mathrm{B}$ and in healthy chronic HBV carriers. Surprisingly, a further decreased $T_{4}: T_{8}$ ratio was noticed in patients with $\mathrm{AH}$ type B. However, normal levels of the ratio were found in the negative normal subjects and in the antibody positive normal subjects. Alexander et al. ${ }^{61}$ suggested that the increased proportion of suppressor/cytotoxic lymphocytes in the peripheral blood of HBsAg carriers represents an increase in the cytotoxic and not the suppressor cell subset and that this is a consequence of active viral replication and not the severity of hepatic inflammation. He suggested that defective suppressor cell function may be one factor in the development of chronic active hepatitis, but it is not reflected by alteration in the $T_{4} / T_{8}$ ratio.

Our results suggested that the proliferation of CTL, which clears viral infected cells, might predominate and alter the ratios in acute and chronic $\mathrm{HBV}$ infection. T cell cytotoxity was shown to be increased in HBsAg carriers which have shown a relationship with $\mathrm{HBe}$ in serum" or with $\mathrm{HBcAg}$ in the liver. ${ }^{8)}$ But further analysis about the subdivided phenotypes of $T_{\mathbf{B}}$ cells is needed in chronic hepatitis and chronic healthy carriers. It has been shown that one of the cytokinins, IL-2, plays a central role in controlling the proliferation of lymphocytes and IL-2 acts by binding to the receptor on the surface of lymphocytes. "1. 12) It was reported that the number of IL-2 receptors rapidly increased and reached a peak level at 2 to 3 days after antigenic and mitogenic stimulation. ") Uchiyama et al. ${ }^{13}$ observed that anti-Tac antibody was reactive with a proportion of normal human peripheral blood $T$ cells activated by PHA $(54.7 \%)$ or Con A $(20.6 \%)$. However, Reske-Kunz et $\mathrm{al}_{\text {. }}$ ) reported that the percentage of receptorpositive blasts was higher on specific $T$ cell ines after antigenic stimulation and their results are in agreement with data by Cantrel and Smith's) obtained with PHA-stimulated human peripheral blood mononuclear cells. Our results showed similiar levels to the above investigators' results after PHA-stimulation or Con A-stimulation. But the percentage of IL-2 receptor positive cells showed significantly lower levels in pa- tients with chronic active hepatitis and in negative normal controls than in the anti-HBs positive control group after specific antigenic stimulation. The findings reported here suggest an explanation for the observation by many investigators ${ }^{16.17)}$ that $\mathrm{HBs}$ has weak or non-existant antigenic properties in $\mathrm{CAH}$ type $B$. Therefore, we think that other antigens such as hepatitis $B$ core antigen ( $\mathrm{HBc}$ ) as well as $\mathrm{HBs}$ could play a major role in antigenicity to chornic HBV infection.

For the most extensively analyzed CTL, the IL-2 receptor levels were maximal at 2-3 days after antigenic stimulation and disappeared thereafter. IL-2 receptors expressed on the cell surface as a consequence of antigenic stimulation are present at high levels for only a limited period of time and are progressively lost from the activated $T$ lymphocyte, ${ }^{18)}$ so it was suggested that antigens plays a primary role in regulating $T$ lymphocyte activation and proliferation. ${ }^{19)}$ The magnitude of proliferation of CTL in response to exogenous IL-2 alone was proportional to the level of IL-2 receptors expressed on the CTL population at a given time after activation. ${ }^{18}$ ) In acute and chronic HBV infection, HBs antigen is continuously released into the serum of the patients and this antige appears on the surface of the hepatocyte membrane. In acute hepatitis, the mononuclear cell infiltration in the liver is composed chiefly of cytotoxic $T$ and NK cells. ${ }^{20}$ ' The lysis of infected hepatocytes, in association with production of virus neutralizing antibody, is responsible for recovery. Thus, defects in the mechanism of elimination of infected hepatocytes and neutralization of infectious virus particles have been postulated to develop chronic infection. The appearance of HBV surface antigen on the infected hepatocyte membrane, ${ }^{211}$ the absence of a humoral antibody to HBs response in chronic infection, and moreover, the demonstration of cellular sensitization to this antigen in an acute infection ${ }^{22)}$ indicate that HBs may be one of the most important viral target antigens.

According to the above concept, it was suggested that after HBs stimulation, IL-2 receptors were expressed on the CTL defectively in patients with $\mathrm{CAH}$ type $\mathrm{B}$ or in HBV carriers and abnormal proliferation response followed after the activation through the inadequate $\mathrm{IL}-2$ receptors. Thus, we tried to investigate whether there was abnormal proliferation of CTL through the IL-2 receptors after IL-2 stimulation. The level of thymidine uptake in the patients with AH type B only was increased significantly, compared with the negative normal control group. This implied that a higher level of IL-2 receptor on 


\section{IMPARIED INTERLEUKIN-2 RECEPTOR EXPRESSION ON LYMPHOCYTES FROM PATIENTS WITH CHRONIC ACTIVE HEPATITIS TYPE B}

CTL was expressed in patients with AH type B than in the other groups. On the other hand, in patients with $\mathrm{CAH}$ type $\mathrm{B}$, increased thymidine uptake was shown but not significantly and the value was lower than that in patients with acute hepatitis $B$. The proliferation response in chronic HBV carriers was similiar to that of the negative normal controls. Our results indicated that in the patients with $\mathrm{CAH}$ type $B$, although a relatively increased number of $T_{8}$ cells and decreased $T_{4} / T_{8}$ ratio was found, there was no significant increase of $\mathrm{IL}-2$ receptor expression and proliferative response. On the contrary, in patient with $\mathrm{AH}$ type $\mathrm{B}$, as compared with the antibody positive control group, there were significant increases of $\mathrm{IL}-2$ receptor expression after HBs stimulation and cellular proliferative response after rIL-2 stimulation, in addition to a decreased $T_{4} / T_{8}$ ratio.

Thus we concluded that, although the number of $\mathrm{T}_{8}$ cells relatively increased, the impaired expression of IL-2 receptors on the $T_{8}$ cells caused a defective response of proliferation in patients with $\mathrm{CAH}$ and this might be one of the immunopathogenic roles of chronicity.

\section{REFERENCES}

1. Andrew ME, Churilla AM, Malek TR, Braciale VL, Braciale TJ: Activation of virus specific CTL clones; Antigen-dependent regulation of interleukin-2 receptor expression. J immunol 124:920, 1985

2. Larsson $E$, Coutinho A, Martinez-A C: A suggested mechanism for $T$ lymphocyte activation; Implications on the acquisition of functional reactivities. Immunol Rev 51:61, 1980

3. Kaplan DR, Braciale VL, Braciale TJ: Antigendependent regulation of interleukin-2 receptor expression on cloned human cytotoxic $T$ lymphocytes. $J \mathrm{Im}$ munol 133:1966, 1984

4. Thomas HC, Brown D, Routhier G, Janossy G, Kung PC, Goldstein G, Sherlock S: Inducer and suppressor $T$ cells in hepatitis $B$ virus induced liver disease. Hepatology 2:202, 1982

5. Regenstein FG, Roodman ST, Perrillo RP: Immunoregulatory $T$ cell subsets in chronic hepatitis $B$ virus infection; the influence of homosexuality. Hepatology 3:951, 1983

6. Alexander GJM, Nouri-Aria KT, Eddleston ALWF, Williams R: Contrasting relations between suppressor cell function and suppressor cell number in chronic liver disease. Lancet 1:1291, 1983

7. Mieli-Vergani $G$, Vergani D, Portmann $B$, White $Y$,
Murray-Lyon I, Marigold JH, Woolf I, Eddleston ALWF, Williams R: Lymphocyte cytotoxicity to autologous hepatocytes in HBsAg positive chronic liver disease. Gut 23:1029, 1982

8. Mondelli M, Mieli-Yergani G, Alberti A, Vergani D, Portmann B, Eddleston ALWF, Williams R: Specificity of T-lymphocyte cytotoxicity to autologous hepatocytes in chronic hepatitis $B$ virus infection; evidence that $T$ cells are directed against $\mathrm{HBV}$ core antigen expressed on hepatocytes. J Immunol 129:277, 1982

9. Morgan DA, Ruscetti FW, Gallo R: Selective in vitro growth of $T$ lymphocytes from normal human bone marrows. Science 193:1007, 1976

10. Smith KA: $T$ cell growth factor. Immunol Rev $51: 337$, 1980

11. Bonnard GD, Yakaka K, Jacobson D: Ligand-activated $T$ cell growth factor induced proliferation; absorption of $T$ cell growth factor by activated $T$ cells. J Immunol 123:2704, 1979

12. Robb RJ, Munck A. Smith KA: T cell growth factor receptors. Quantitation, specificity, and biological relevance. J Exp Med 154:1455, 1981

13. Uchiyama T, Broder S, Waldmann TA: A monoclonal antibody (anti-Tac) reactive with activated and functionally mature human T cells. J Immunol 126:1393. 1981

14. Reske-kunz $A B$, Steldern $D r$, Rüde $E$, Osawa $H$, Diamanstein $T$ : Interkeukin-2 receptors on an insulinspecific $T$ cell line; Dynamics of receptor expression. $J$ Immunol 133:1356, 1984

15. Cantrell DA, Smith KA: Transient expression of interleukin-2 receptors. Consequences for $T$ cell growth. J Exp Med 158:1895, 1983

16. Hanson RG, Hoonagle JH, Minuk GY, Purcell RH, Gerin JL: CEll-mediated immunity to hepatitis $B$ surface antigen in man. Clin Exp Immunol 57:257, 1984

17. Ferrari $C$, Amalia $P$, Sansoni $P$, Tiziana $G$, Neri TM, Chisari FV, Fiaccadori F: Selective sensitization of peripheral blood $T$ iymphocytes to hepatitis $B$ core antigen in patients with chronic active hepatitis type $B$. Clin Exp Immunol 67:497, 1986

18. Andrew ME, Churilla AM, Malek TR, Braciale VL, Braciale TJ: Activation of virus specific CTL clones; antigen-dependent regulation of interleukin 2 receptor expression. J Immunal 134:920, 1985

19. Kapian D, Braciale VL, Braciale TJ: Antigen-dependent regulation of interleukin 2 receptor expression of cloned human cytotoxic T lymphocytes. J Immunol 133:1966, 1984

20. Stites DP, Stobo JD, Well JV: Basic and Clinical Immunology, 6th ed. p.649, Norwalk California, Appleton and Lange 1987

21. Brechot C, Hadchouel M. Scotto J, Degos F, Charnay 
$P$, Trepo $C$, Tiollais $P$ : Detection of hepatitis $B$ virus DNA in liver and serum: $A$ direct appraisal of the chronic carrier state. Lancet 2:765, 1982

22. Shafritz D, Shouval D, Sherman H, Hadziyannis SJ,
Kew $\mathrm{M}$ : Integration of hepatitis $B$ viris into the genome of liver cells in chronic liver disease and hepatocellular carcinoma. Studies in percutaneous liver biopsies and post-mortem tissue specimens. N Engl J Med 305:1067, 1982 